\title{
Characterization of incubation experiments and development of an enrichment culture capable of ammonium oxidation under iron-reducing conditions
}

\author{
S. Huang and P. R. Jaffé \\ Department of Civil and Environmental Engineering, Princeton University, Princeton, NJ 08544, USA \\ Correspondence to: P. R. Jaffé (jaffe@ @rinceton.edu) \\ Received: 14 July 2014 - Published in Biogeosciences Discuss.: 14 August 2014 \\ Revised: 28 November 2014 - Accepted: 1 December 2014 - Published: 10 February 2015
}

\begin{abstract}
Incubation experiments were conducted using soil samples from a forested riparian wetland where we have previously observed anaerobic ammonium oxidation coupled to iron reduction. Production of both nitrite and ferrous iron was measured repeatedly during incubations when the soil slurry was supplied with either ferrihydrite or goethite and ammonium chloride. Significant changes in the microbial community were observed after 180 days of incubation as well as in a continuous flow membrane reactor, using $16 \mathrm{~S}$ rRNA gene PCR-denaturing gradient gel electrophoresis, 454 pyrosequencing, and real-time quantitative PCR analysis. We believe that one of the dominant microbial species in our system (an uncultured Acidimicrobiaceae bacterium A6), belonging to the Acidimicrobiaceae family, whose closest cultivated relative is Ferrimicrobium acidiphilum (with $92 \%$ identity) and Acidimicrobium ferrooxidans (with $90 \%$ identity), might play a key role in this anaerobic biological process that uses ferric iron as an electron acceptor while oxidizing ammonium to nitrite. After ammonium was oxidized to nitrite, nitrogen loss proceeded via denitrification and/or anammox.
\end{abstract}

\section{Introduction}

The most common removal of nitrogen from soil environments is mineralization (for organic nitrogen), followed by nitrification and then denitrification (Canfield et al., 2010). In water-saturated and organic carbon rich sediments or soils, such as wetland sediments, there is little oxygen for significant nitrification by aerobic ammonium $\left(\mathrm{NH}_{4}^{+}\right)$oxidation bacteria/archaea (AOB/AOA). A novel anaerobic $\mathrm{NH}_{4}^{+}$oxidation process coupled to iron reduction was first noted in a forested riparian wetland in New Jersey (Clement et al., 2005). In this reaction, $\mathrm{NH}_{4}^{+}$is the electron donor, which is oxidized to nitrite $\left(\mathrm{NO}_{2}^{-}\right)$, and ferric iron - $\mathrm{Fe}(\mathrm{III})-$ is the electron acceptor, which is reduced to ferrous iron $-\mathrm{Fe}$ (II). The stoichiometry and change in free energy when ferrihydrite is the $\mathrm{Fe}(\mathrm{III})$ source is:

$3 \mathrm{Fe}_{2} \mathrm{O}_{3} \bullet 0.5 \mathrm{H}_{2} \mathrm{O}+10 \mathrm{H}^{+}+\mathrm{NH}_{4}^{+} \rightarrow 6 \mathrm{Fe}^{2+}$

$+8.5 \mathrm{H}_{2} \mathrm{O}+\mathrm{NO}_{2}^{-}\left(\Delta G_{\mathrm{r}} \leq-145.08 \mathrm{~kJ} \mathrm{~mol}^{-1}\right.$, Supplement 1.1$)$

No proven pathway for the oxidation of $\mathrm{NH}_{4}^{+}$to $\mathrm{NO}_{2}^{-}$in anaerobic environments has been described in the literature before this process was reported. Using labeled ${ }^{15} \mathrm{NH}_{4}^{+}$in a microcosm experiment resulted in the production of ${ }^{15} \mathrm{~N}_{2}$, which conclusively showed that ammonium-N was converted to nitrogen gas $\left(\mathrm{N}_{2}\right)$ in these sediments under iron-reducing conditions (Shrestha et al., 2009). Either this same pathway for $\mathrm{NH}_{4}^{+}$oxidation, or a very similar one, was also observed in a biological reactor (Sawayama, 2006) and a tropical rainforest soil (Yang et al., 2012), and coined Feammox (Sawayama, 2006). These pathways have been reported to oxidize $\mathrm{NH}_{4}^{+}$to $\mathrm{NO}_{2}^{-}$(Clement et al., 2005; Shrestha et al., 2009), to $\mathrm{NO}_{3}^{-}$(Sawayama, 2006), or directly to $\mathrm{N}_{2}$ (Yang et al., 2012), using Fe(III) as an electron acceptor.

Our understanding of the Feammox process is still incomplete; particularly, information about the microorganism(s) responsible for it is lacking. This makes further study into the mechanism of the Feammox process difficult. Here we focus on a series of incubations and establishing a Feammox 
enrichment culture to identify the microbial community responsible for the process described previously (Clement et al., 2005; Shrestha et al., 2009). Soil samples were collected from the same location and used for laboratory incubation experiments as well as to set up an enrichment system for Feammox in a continuous flow membrane reactor. Various incubation conditions ( $\mathrm{Fe}(\mathrm{III})$ sources, inorganic carbon content, $\mathrm{NH}_{4}^{+}$concentration, ${ }^{15} \mathrm{NH}_{4}^{+}$, and acetylene gas $\left(\mathrm{C}_{2} \mathrm{H}_{2}\right)$ as a selected inhibitor) were used to study the Feammox mechanism. Molecular biology methods, such as denaturing gradient gel electrophoresis (DGGE), 454 pyrosequencing, and real-time quantitative PCR (qPCR) analysis were used to investigate the bacterial community change during incubations.

\section{Methods}

\subsection{Sample collection and processing}

Soils for all the experiments described in this study were taken from a temperate forested riparian wetland at the Assunpink Wildlife Management Area, New Jersey. Ten soil cores were collected from $10 \mathrm{~cm}$ below the surface with polyethylene column containers $(8 \mathrm{~cm}$ diameter and $30 \mathrm{~cm}$ long) and transported to the laboratory within $2 \mathrm{~h}$. The soil $\mathrm{pH}$ was between 3.5 and 4.5 , and no manganese oxides were detected. The detailed physicochemical characteristics of these wetland soils have been described elsewhere (Clement et al., 2005). Prior to all incubation experiments, soil slurry from the field site was aerated for a month to degrade much of the labile organic carbon. After 30 days of aeration, the dissolved organic carbon (DOC) content was stable at $2.06 \pm 0.20 \mathrm{mg} \mathrm{g}^{-1}$. Following the aeration treatment, the soil was divided into $400 \times 10 \mathrm{~g}$ (air-dry equivalent) subsamples, and added to $50 \mathrm{~mL}$ serum vials, with $30 \mathrm{~mL}$ deionized water. The soil slurries were purged thoroughly with a $\mathrm{CO}_{2}: \mathrm{N}_{2}(80: 20)$ mixture, resulting in a final $\mathrm{pH}$ of $\sim 4$ to 4.5. The vials were sealed tightly with rubber stoppers and were stored in an anaerobic glove box for 30 days at ambient temperature to allow for stabilization before starting the incubations.

\subsection{Batch incubation experiments}

All incubations, addition of reagents, and sampling were conducted in an anaerobic glove box with a solution of resazurin as the redox indicator. Soil samples were first incubated with different $\mathrm{Fe}$ (III) sources to determine which source would yield a more active Feammox process: 6-line ferrihydrite $\left(\mathrm{Fe}_{2} \mathrm{O}_{3} \mathrm{C} \cdot 0.5 \mathrm{H}_{2} \mathrm{O}\right)$ or goethite $(\mathrm{FeO}(\mathrm{OH})$; prepared according to Cornell and Schwertmann, 2003) $+\mathrm{NH}_{4}^{+}$addition; ferric chloride $+\mathrm{NH}_{4}^{+}$addition; ferric citrate $+\mathrm{NH}_{4}^{+}$addition; either only ferrihydrite or $\mathrm{NH}_{4}^{+}$addition; and autoclaved soil with ferrihydrite $+\mathrm{NH}_{4}^{+}$addition $(n=30$ per treatment). $\mathrm{pH}$ was adjusted to 4.5 in the ferrihydrite/goethite augmented samples, and to between 3.5 and $\sim 4.0$ in the ferric chloride/citrate augmented samples. Soil-slurry samples, which were prepared to have an initial concentration of $12.0 \mathrm{mmol} \mathrm{L}^{-1} \mathrm{Fe}(\mathrm{III})$ and/or $2.00 \mathrm{mmol} \mathrm{L}^{-1} \mathrm{NH}_{4}^{+}$, were incubated in a series of $50 \mathrm{~mL}$ vials with an oxygen-free headspace, created by purging with a $\mathrm{CO}_{2}: \mathrm{N}_{2}(80: 20)$ mixture. Triplicate samples were collected destructively every 2 days to analyze iron and nitrogen species.

The second incubation was conducted to extend the anoxic incubation with ferrihydrite to 180 days, with repeated $\mathrm{NH}_{4} \mathrm{Cl}$ additions after the $\mathrm{NH}_{4}^{+}$in solution was exhausted. The initial concentration of Fe(III) was 25.0 and $1.00 \mathrm{mmol} \mathrm{L}^{-1} \mathrm{NH}_{4}^{+}$was added on days 4, 24, and 60; furthermore, $0.20 \mathrm{mmol} \mathrm{L}^{-1} \mathrm{NaHCO}_{3}$ was added on day 50 and day 90 of the incubation. On day 125, incubation vials were divided into two sets to study the effect of different inorganic carbon contents on Feammox. Either 1.20 or $0.20 \mathrm{mmol} \mathrm{L}^{-1}$ of $\mathrm{NaHCO}_{3}$ plus $2 \mathrm{mmol} \mathrm{L}^{-1}$ of $\mathrm{NH}_{4} \mathrm{Cl}$ were added to each set. $\mathrm{NaHCO}_{3}$ was then added every 10 days, which increased the soil $\mathrm{pH}$ to $\sim 5$ in the samples amended with $1.20 \mathrm{mmol} \mathrm{L}^{-1}$ or $\mathrm{NaHCO}_{3}$. For this incubation, samples were collected every 4 days. Finally, soil samples collected on day 180 of the incubations were used to enrich the Feammox bacteria in a membrane reactor. To study how the organic carbon content affects the Feammox bacteria, $1.00 \mathrm{mmol} \mathrm{L}^{-1}$ sodium citrate was also supplied on day 125 to four of the $1.20 \mathrm{mmol} \mathrm{L}^{-1} \mathrm{NaHCO}_{3}$ amended samples.

In the third experiment, inorganic nitrogen species were quantified through incubations in the presence of $\mathrm{C}_{2} \mathrm{H}_{2}$. Soil slurries were first incubated for 90 days in eighty $50 \mathrm{~mL}$ vials. The $\mathrm{Fe}(\mathrm{III})$ concentration at the beginning of the incubations was $25 \mathrm{mmol} \mathrm{L}^{-1}$. One $\mathrm{mmol} \mathrm{L}^{-1} \mathrm{NH}_{4} \mathrm{Cl}$ and $0.20 \mathrm{mmol} \mathrm{L}^{-1} \mathrm{NaHCO}_{3}$ were added on days 24, 60, and 90 . After this incubation, $5 \mathrm{~mL}$ of pure $\mathrm{C}_{2} \mathrm{H}_{2}$ gas were added to 40 vials, which resulted in a final $\mathrm{C}_{2} \mathrm{H}_{2}$ concentration of $100 \mu \mathrm{mol} \mathrm{L}^{-1}$. Samples with and without $\mathrm{C}_{2} \mathrm{H}_{2}$ were then incubated anaerobically for 20 days. The headspace gas was sampled every $24 \mathrm{~h}$ for $\mathrm{N}_{2} \mathrm{O}$ analysis, and soil samples were analyzed every 2 days for $\mathrm{Fe}$ and $\mathrm{N}$ species.

\subsection{Continuous flow membrane Feammox reactor}

Soil samples collected on day 180 from the incubation with ferrihydrite, $\mathrm{NH}_{4} \mathrm{Cl}$, and $1.20 \mathrm{mmol} \mathrm{L}^{-1} \mathrm{NaHCO}_{3}$ additions were inoculated into a continuous flow membrane reactor (Abbassi et al., 2014), which was operated under anaerobic conditions by constantly purging $\mathrm{N}_{2}$ through the reactor's headspace at room temperature $\left(25^{\circ}\right)$, and with a $48 \mathrm{~h}$ hydraulic retention time.

The enrichment medium contained the following components per liter: $177 \mathrm{mg} \mathrm{NH} \mathrm{NH}_{4} \mathrm{Cl} 77.9 \mathrm{mg}\left(\mathrm{NH}_{4}\right)_{2} \mathrm{SO}_{4}$, $19.8 \mathrm{mg} \mathrm{NaHCO}_{3}, 71.0 \mathrm{mg} \mathrm{KHCO}_{3}, 9.00 \mathrm{mg} \mathrm{KH} \mathrm{K}_{2} \mathrm{PO} 4$, $100 \mathrm{mg} \mathrm{MgSO}_{4} \times 7 \mathrm{H}_{2} \mathrm{O}$, and $60.0 \mathrm{mg} \mathrm{CaCl} \times 2 \mathrm{H}_{2} \mathrm{O}$. After autoclaving, $1 \mathrm{~mL}$ trace element solution (Van de Graaf 
et al., 1996) was added to the medium. $50.0 \mathrm{mmol} \mathrm{L}^{-1}$ ferrihydrite were added once every 2 weeks directly into the reactor. To aid in maintaining anaerobic conditions, 0.10 $0.20 \mathrm{mmol} \mathrm{L}^{-1}$ sodium citrate were fed to the reactor about twice per month. $\mathrm{pH}$ was controlled at around $4 \sim 5$, and dissolved oxygen was less than $0.10 \mathrm{mg} \mathrm{L}^{-1}$. Samples from the outflow were collected every 2 days, and sludge samples from the reactor were collected and kept at $-20^{\circ} \mathrm{C}$ for molecular biology analysis.

Finally, ${ }^{15} \mathrm{~N}$ isotope tracer incubations were conducted using slurries collected form the stable Feammox membrane reactor. Five treatments ( $n=3$ per treatment) were conducted: (1) control with only anoxic deionized (DI) water; (2) ${ }^{15} \mathrm{NH}_{4} \mathrm{Cl}$ addition; (3) ${ }^{15} \mathrm{NH}_{4} \mathrm{Cl}+\mathrm{Fe}$ (III) addition; (4) ${ }^{15} \mathrm{NH}_{4} \mathrm{Cl}$ and $\mathrm{C}_{2} \mathrm{H}_{2}$ addition; and (5) ${ }^{15} \mathrm{NH}_{4} \mathrm{Cl}, \mathrm{C}_{2} \mathrm{H}_{2}$, and $\mathrm{Fe}(\mathrm{III})$ addition. The headspace gas of each $50 \mathrm{~mL}$ incubation vial was sampled every $24 \mathrm{~h}$ for ${ }^{15} \mathrm{~N}_{2} \mathrm{O}$ analysis (Supplement 1.4).

\subsection{Chemical analyses}

For each sample collection during the incubations, a set of vials was destructively sampled in a glove box under oxygenfree conditions and the $\mathrm{pH}$ was measured immediately using a $\mathrm{pH}$ electrode. An extraction with $0.5 \mathrm{~N} \mathrm{HCl}$ was conducted for $24 \mathrm{~h}$ at room temperature to determine acid-extractable $\mathrm{Fe}$ (II) and $\mathrm{NH}_{4}^{+}$concentrations in the soils. Fe(II) was analyzed using the ferrozine assay method (Stookey, 1970; Komlos et al., 2007). Extraction efficiency of Fe(II) was affected by the $\mathrm{HCl}$ concentration and the extraction time. About 5-10\% more Fe(II) could be extracted with either 1N $\mathrm{HCl}$ extraction over $24 \mathrm{~h}$ or with $0.5 \mathrm{~N} \mathrm{HCl}$ over $36 \mathrm{~h}$ as opposed to $0.5 \mathrm{~N} \mathrm{HCl}$ over $24 \mathrm{~h}$. Furthermore, after more Fe(II) was produced in the system with increasing incubation time, the $\mathrm{Fe}(\mathrm{II})$ extraction efficiency improved. Only a $1-2 \%$ difference was observed in the $\mathrm{Fe}(\mathrm{II})$ extracted over $24 \mathrm{~h}$ using $0.5 \mathrm{~N}$ vs. $1 \mathrm{~N} \mathrm{HCl}$ towards the end of the incubation period. Clays, present in the soil incubations, typically sorb Fe(II) more efficiently when the total $\mathrm{Fe}(\mathrm{II})$ is low; furthermore, ferrihydrite is slowly converted to magnetite, resulting in relatively different associations with different phases of the $\mathrm{Fe}$ (II) over the duration of the incubation. All of which leads to incomplete $\mathrm{Fe}$ (II) extractions, especially when the $\mathrm{Fe}$ (II) is low. Here we report $\mathrm{Fe}$ (II) data obtained via $0.5 \mathrm{~N} \mathrm{HCl}$ extractions over $24 \mathrm{~h}$ to ensure that the methods and hence data are comparable to those reported by other researchers focusing on iron reduction and iron bioavailability.

$\mathrm{NH}_{4}^{+}$was analyzed using a Dionex ${ }^{\mathrm{TM}}$ ion chromatograph (LC3000) with a CS-16 column and a CS-16 guard column (flow rate $=1.00 \mathrm{~mL} \mathrm{~min}^{-1}$, detection limit $=0.012 \mathrm{ppm}$ ). $\mathrm{NO}_{3}^{-}$and $\mathrm{NO}_{2}^{-}$were extracted with DI water for $1 \mathrm{~h}$ anaerobically, and measured via ion chromatography, using an AS-22 column along with an AG-22 guard column (flow rate $=1.20 \mathrm{~mL} \mathrm{~min}^{-1}$, detection limit $=0.016 \mathrm{ppm}$ ). For the total organic carbon (TOC) and total nitrogen (TN) analy- ses, a Shimadzu TOC-5000(A) was used. $\mathrm{N}_{2} \mathrm{O}$ concentrations were determined on a Shimadzu 2014 gas chromatograph equipped with an electron capture detector.

\subsection{DNA and RNA isolation}

DNA and RNA samples were extracted from soils collected at the wetland prior to any laboratory incubation, from the samples taken at different time points during the incubation experiments, and from the reactor. DNA was extracted from $500 \mathrm{mg}$ soil or sludge samples using the FastDNA ${ }^{\circledR}$ spin kit for soil (MP Biomedicals, USA) as described by the manufacturer, and RNA using the FastRNA ${ }^{\circledR}$ pro Soil Direct Kit. The concentrations were measured using a Nano-drop 2000 spectrophotometer (Thermo Scientific, USA).

\subsection{PCR-DGGE and 454 pyrosequencing analysis}

Bacterial universal 16S rRNA gene primer sets V3-2/V3-3 (Jensen et al., 1998) were used for PCR amplification (Table 1). DGGE was performed with an $8 \%$ polyacrylamide gel containing a gradient from 40 to $80 \%$ denaturant using the gradient gel electrophoresis system (C.B.S. SCIENTIFIC, USA). The electrophoresis was carried out at $60 \mathrm{~V}$ for $15 \mathrm{~h}$. After that the gel was stained with $0.1 \mu \mathrm{L} \mathrm{mL}^{-1}$ SYBR Green I and visualized with an UV transilluminator. All visible bands were excised from the gel and used as templates for re-amplification, using primer set V3-1/V3-2 (Jensen et al., 1998) and followed by cloning (Table 1). PCR products were purified via agarose gel extraction and cloned into a pGEM$\mathrm{T}$ vector (Promega). A total of 10 to 30 positive recombinant clones for each band were identified by colony PCR, and were sent for sequencing to avoid erroneous interpretations. DNA sequencing was then conducted by Genewiz, Inc. Bacteria were classified and the phylogenetic tree of Acidimicrobiaceae-related sequences was constructed using the Bayesian inference (Huelsenbeck et al., 2001) (Supplement 1.2). Sequences obtained in this study are available in the GenBank database under accession numbers KC581755KC581779. To confirm the changes in the bacterial community further, 454 pyrosequencing was performed with samples collected from the incubation on days $0,30,90$, and 160 , and from the membrane reactor after 150 days of reactor operation. Domain-specific primers Bact-338F1/909R, targeting the V3-V5 region of the $16 \mathrm{~S}$ rDNA of bacteria, were amplified and sequenced following methods suggested by Pinto et al. (2012) (Supplement 1.2).

\subsection{Quantitative PCR (qPCR) assay}

qPCR experiments were carried out using a StepOnePlus ${ }^{\text {TM }}$ Real-Time PCR System (Life Technologies, USA), represented by $16 \mathrm{~S}$ rRNA genes, using primer sets $1055 \mathrm{f} / 1392 \mathrm{r}$ for total bacteria (Harms et al., 2003), Amx368f/Amx820r for anammox bacteria (Schmid et al., 2000; Schmid et al., 2003), acd320f-432r, which we developed for 
Table 1. Sequence analysis of bands excised from DGGE gels of soil samples with Feammox activity.

\begin{tabular}{|c|c|c|c|}
\hline Phylogenetic group & Band & Related sequence & Identity $(\%)$ \\
\hline \multirow[t]{6}{*}{ Actinobacteria } & \multirow[t]{4}{*}{ A6, B1, D6 } & Ferrimicrobium acidiphilum strain T23 16S & 92 \\
\hline & & Ribosomal RNA gene (AF251436) & \\
\hline & & Acidimicrobium ferrooxidans strain TH3 $16 \mathrm{~S}$ & 90 \\
\hline & & Ribosomal RNA gene (EF621760) & \\
\hline & \multirow[t]{2}{*}{ A6 } & Uncultured Ferrimicrobium sp. clone D. an-41 $16 \mathrm{~S}$ & 95 \\
\hline & & Ribosomal RNA gene (JX505108) & \\
\hline \multirow[t]{5}{*}{ Acidobacteria } & \multirow[t]{5}{*}{ A8, D11 } & Uncultured Acidobacteria bacterium clone 3OL11 & 97 \\
\hline & & $16 \mathrm{~S}$ & \\
\hline & & Ribosomal RNA gene (GQ342349) & \\
\hline & & Geothrix sp. culture clone AP-FeEnrich1 16S & 94 \\
\hline & & Ribosomal RNA gene (JX828409) & \\
\hline \multirow[t]{4}{*}{ BetaProteobacteria } & \multirow[t]{2}{*}{ A9, B9, C4, D14 } & Uncultured Rhodocyclus sp. clone W4S68 16S & 97 \\
\hline & & Ribosomal RNA gene (AY691423) & \\
\hline & \multirow[t]{2}{*}{ A9 } & Comamonas sp. "ARUP UnID 223” $16 \mathrm{~S}$ & 97 \\
\hline & & Ribosomal RNA gene (JQ259419) & \\
\hline
\end{tabular}

Acidobacteriaceae bacteria, and acm $342 \mathrm{f}-439 \mathrm{r}$, which we developed for Acidimicrobiaceae bacteria (Supplement 1.3) (Table 1). For the detection of denitrifiers, AOB and AOA, denitrifying functional genes (nirS and nirk), ammonia monooxygenase structural genes (amoA) were quantified with primer sets NirS3F/NirS5R, NirK1F/NirK5R (Braker et al., 1998) and amoA-1F/amoA-2R (Rotthauwe et al., 1997) for AOB-amoA and Arch amoA-F/amoA-R for AOAamoA (Francis et al., 2005), respectively. Primer pairs CrenamoA23f/616r were also used to quantify the thaumarchaeal amoA genes that represented acidophilic ammonia oxidizers (Tourna et al., 2008). For DNA quantification, each qPCR mixture $(20 \mu \mathrm{L})$ was composed of $10 \mu \mathrm{L}$ of SYBR Premix Ex Taq ${ }^{\circledR}$ II (Takara, Japan), $0.8 \mu \mathrm{L} 10 \mu \mathrm{M}$ of each primer, and $\sim 10$ ng DNA template. RNA quantification was conducted through a real-time quantitative reverse transcription PCR (RT-qPCR) analysis, by using the One Step SYBR ${ }^{\circledR}$ PrimeScript ${ }^{\circledR}$ RT-PCR Kit (Takara, Japan) according to the manufacturer's recommendations. Thermal cycling conditions for total 16S rDNA, nirS and AOB-amoA gene numbers were initiated for $30 \mathrm{~s}$ at $94^{\circ} \mathrm{C}$, followed by 40 cycles of $5 \mathrm{~s}$ at $94^{\circ} \mathrm{C}, 30 \mathrm{~s}$ at $57^{\circ} \mathrm{C}$, and $30 \mathrm{~s}$ at $70^{\circ} \mathrm{C}$. $16 \mathrm{~S}$ rDNA numbers of anammox, Acidobacteriaceae and Acidimicrobiaceae bacteria were performed at 56,55 and $58^{\circ} \mathrm{C}$ as annealing temperatures, respectively, with the same program. For the AOB-amoA gene and the thaumarchaeal amoA genes, the annealing temperatures were 53 and $55^{\circ} \mathrm{C}$, and the annealing time was adjusted to $45 \mathrm{~s}$. For RNA quantification, the cycling conditions were identical to those described for measuring gene numbers, with the exception that an initial incubation was conducted for $5 \mathrm{~min}$ at $42{ }^{\circ} \mathrm{C}$ to facilitate reverse transcriptase activity. Each assay contained a standard using a serial dilution of plasmids containing specific target genes, independent triplicate templates for each soil sample, and triplicate no template controls (NTC).

\section{Results}

\subsection{Change in Fe and $\mathrm{N}$ species under different operational conditions}

After incubating the pre-treated soil slurry with the four different $\mathrm{Fe}$ (III) sources for 30 days, only samples to which either ferrihydrite or goethite had been added showed measurable $\mathrm{NH}_{4}^{+}$oxidation (Fig. 1 and Supplement Fig. S1). In samples incubated with ferric citrate and $\mathrm{NH}_{4} \mathrm{Cl}, \mathrm{Fe}(\mathrm{III})$ reduction was much faster than in those supplied with $\mathrm{Fe}$ (III) oxides, but the $\mathrm{NH}_{4}^{+}$concentration remained fairly constant (Fig. 1). No detectable $\mathrm{Fe}(\mathrm{II})$ reduction or $\mathrm{NH}_{4}^{+}$oxidation was found in the sterilized soils amended with ferrihydrite and $\mathrm{NH}_{4} \mathrm{Cl}$ (Fig. S2). Faster iron reduction and $\mathrm{NH}_{4}^{+}$removal was observed in ferrihydrite than in goethite-amended sediments (Fig. S1).

Since samples incubated with ferrihydrite and $\mathrm{NH}_{4} \mathrm{Cl}$ resulted in the fastest $\mathrm{NH}_{4}^{+}$oxidation, the anaerobic incubation with ferrihydrite was extended to 180 days. Ferrihydrite as the $\mathrm{Fe}(\mathrm{III})$ source results in a larger negative $G$ value than goethite (Clement et al., 2005). The $\mathrm{NH}_{4}^{+}$oxidation rate increased as $\mathrm{NH}_{4} \mathrm{Cl}$ was supplied repeatedly, especially after 125 days of incubation, when the $\mathrm{NaHCO}_{3}$ additions were increased from 0.20 to $1.20 \mathrm{mmol} \mathrm{L}^{-1}$ in addition to the $2.00 \mathrm{mmol} \mathrm{L}^{-1} \mathrm{NH}_{4}^{+}$added. The increased $\mathrm{NaHCO}_{3}$ dosing also increased the generation of Fe(II) (Fig. 2a, b). During the 180-day incubation, the ratio of $\mathrm{Fe}$ (II) produced to $\mathrm{NH}_{4}^{+}$ removed gradually increased until it reached $5.3: 1$ by day 160, after which it remained stable (Fig. S6). 

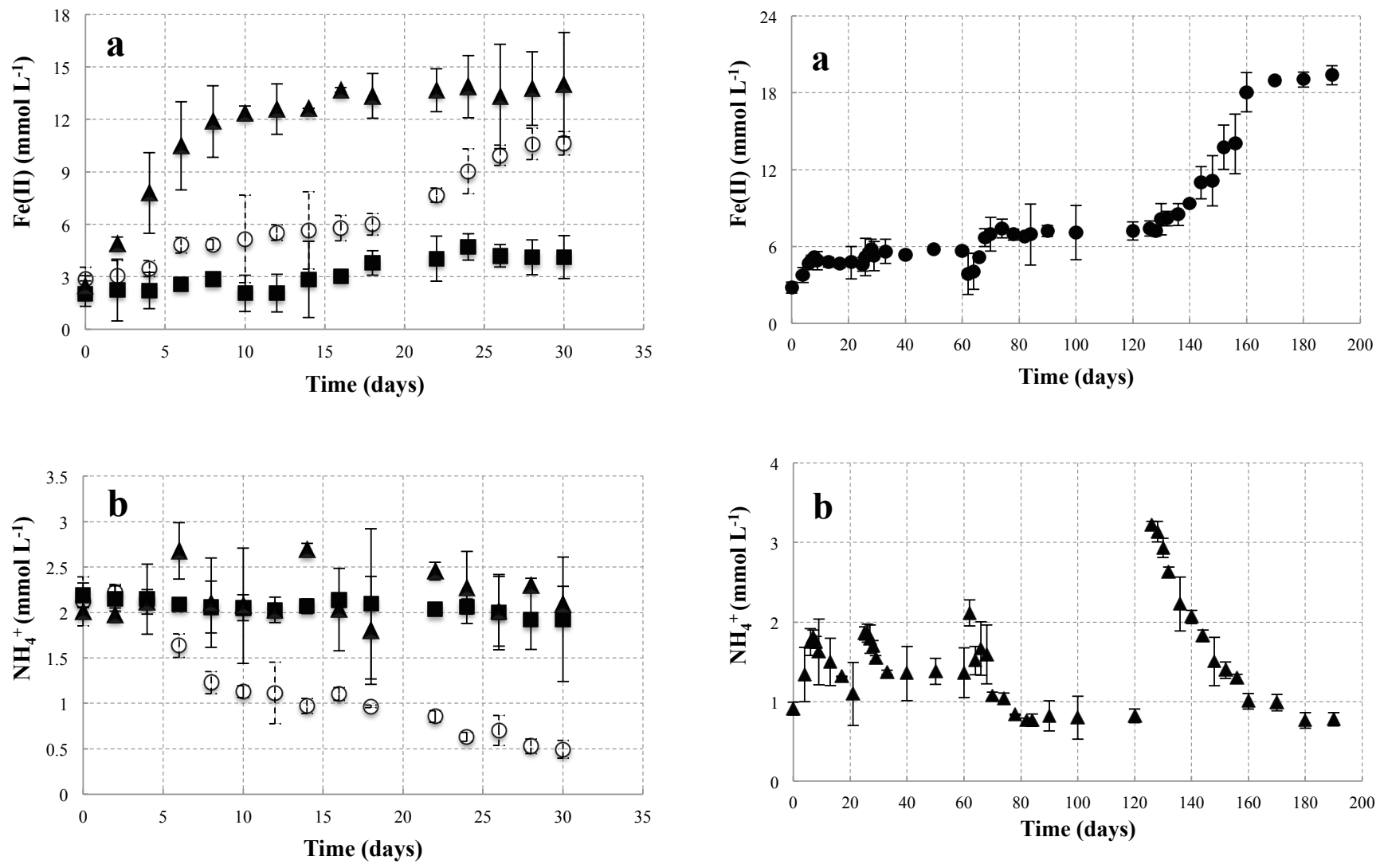

Figure 1. Concentration of $\mathrm{Fe}(\mathrm{II})$ and $\mathrm{NH}_{4}^{+}$in incubation with three different $\mathrm{Fe}(\mathrm{III})$ sources: ferrihydrite (o), ferric chloride (ם), and ferric citrate $(\boldsymbol{\Delta})$. The values represent the mean and standard error $(n=3)$.

$\mathrm{NO}_{2}^{-}$appeared within a few days after the addition of $\mathrm{NH}_{4}^{+}$, with a maximum concentration of $0.44 \pm 0.17 \mathrm{mmol} \mathrm{L}^{-1}$ in the second $\mathrm{NH}_{4}^{+}$oxidation cycle. $\mathrm{NO}_{2}^{-}$did not accumulate in the system and was immediately consumed after generation (Fig. $\mathrm{S} 3 \mathrm{a}$ ). $\mathrm{NO}_{3}^{-}$production showed a similar pattern to that of $\mathrm{NO}_{2}^{-}$(Fig. S3a), and $\mathrm{TN}$ loss similar to the decrease in $\mathrm{NH}_{4}^{+}$(Fig. S3b). During 180 days of incubation, the system experienced a loss of TN of $57.2 \pm 3.13 \mathrm{mg} \mathrm{L}^{-1}$. The DOC content fluctuated slightly in the early stage of incubation, but overall, the DOC concentration was relatively stable at around $45 \sim 50 \mathrm{mg} \mathrm{L}^{-1}$ (Fig. S3b).

A $64.5 \% \mathrm{NH}_{4}^{+}$removal, between inflow and outflow was achieved in the membrane reactor after 150 days of operation.

\subsection{Phylogenetic analysis of the microbial community based on the 16S rRNA gene}

All visible bands observed in the DGGE analysis (significant bands were marked; see Fig. 3) were excised from the gel and sequenced after cloning. Clone libraries from 12 sam-

Figure 2. Concentration of (a) $\mathrm{Fe}$ (II) and (b) $\mathrm{NH}_{4}^{+}$during the 180-day incubation. $25 \mathrm{mmol} \mathrm{L}^{-1} \mathrm{Fe}$ (III) was added on day 0 . $1.0 \mathrm{mmol} \mathrm{L}^{-1} \mathrm{NH}_{4}^{+}$was added on days 4, 24, and 60 . $0.2 \mathrm{mmol} \mathrm{L}^{-1} \mathrm{NaHCO}_{3}$ was added on day 50 and day 90. $1.2 \mathrm{mmol} \mathrm{L}^{-1}+2 \mathrm{mmol} \mathrm{L}^{-1}$ of $\mathrm{NH}_{4} \mathrm{Cl}$ were added on day 125 . The values represent the mean and standard error $(n=3)$.

ples resulted in 721 sequences of partial 16S rRNA gene fragments, and six groups of bacteria were classified via a phylogenetic analysis (Table 1 and Supplement Table S1). During this 180-day anaerobic incubation with ferrihydrite and $\mathrm{NH}_{4} \mathrm{Cl}$, the microbial communities shifted dramatically and the microbial diversity decreased with time (Fig. 3, lanes 1-4). Some DGGE bands disappeared gradually with time, such as band A5 and band A7. Band A5 represents a dissimilatory iron-reducing bacterium, Geobacter $\mathrm{sp}$., which existed in this $\mathrm{Fe}$ (III)-rich wetland soil and reappeared for a short time during the initial anaerobic incubation. Band A7 represents an ammonia-oxidizing bacterium, Nitrosomonas sp., which showed a strong presence in the samples at 30 days of incubation and was attenuated after longer incubation times. In contrast, DGGE bands A6, A8 and A9 became more significant as the incubation time increased, showing that there were three groups of bacteria dominating in the system after 160 days of incubation. Band A6 represents a group of bacteria belonging to the Acidimicrobiaceae family. Bacteria from the Acidobacteriaceae family are represented by band 


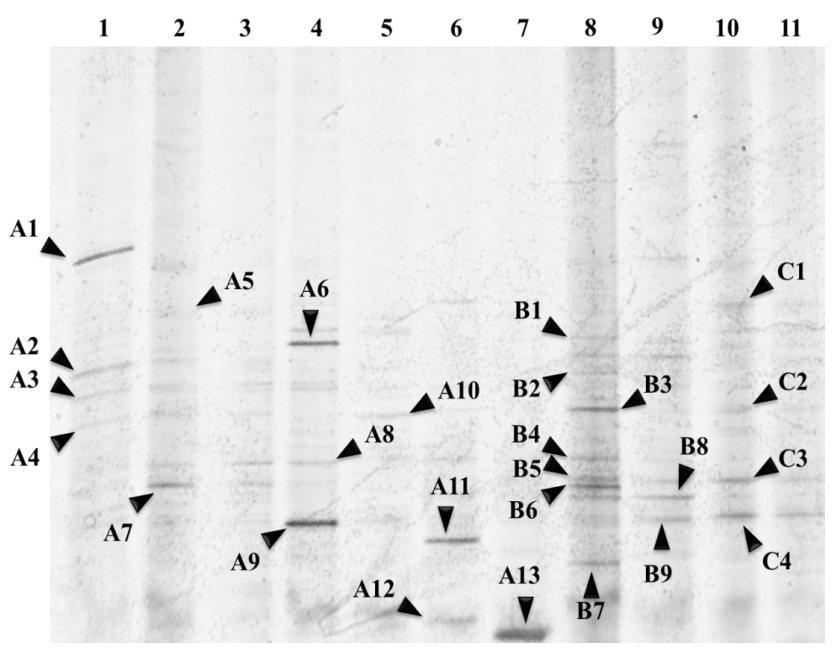

Figure 3. Comparison of DGGE analysis profiles of soil communities during anaerobic incubations. Samples from 0, 30, 90 and 160 days of incubation with ferrihydrite $+\mathrm{NH}_{4} \mathrm{Cl}+\mathrm{NaHCO}_{3}$ (lanes 1-4); 160 days of incubation with only ferrihydrite (lane 5); ferric chloride $+\mathrm{NH}_{4} \mathrm{Cl}$ (lane 6); ferric citrate $+\mathrm{NH}_{4} \mathrm{Cl}$ (lane 7); 120 days incubation with ferrihydrite $+\mathrm{NH}_{4} \mathrm{Cl}+\mathrm{NaHCO}_{3}+$ organic carbon (band 8); ferrihydrite $+\mathrm{NH}_{4} \mathrm{Cl}+$ organic carbon (lane 9). Samples from 6 and 120 days of incubation without any addition (lanes 10 and 11) were used as controls.

A8. Some species in this family have been described as iron reducers and obligate heterotrophs (Kishimoto et al., 1991; Rowe et al., 2007; Coupland and Johnson, 2008). DGGE band A9 represents bacteria of the Rhodocyclaceae family. This family contains mainly denitrifying bacteria, which exhibit very versatile metabolic capabilities (Smith et al., 2005; Huang et al., 2011).

Microbial communities also differed between samples incubated with various $\mathrm{Fe}(\mathrm{III})$ sources, and between samples with or without the addition of inorganic carbon. Samples supplied with either ferric chloride or ferric citrate as the $\mathrm{Fe}(\mathrm{III})$ source plus $\mathrm{NH}_{4}^{+}$, and samples supplied with just ferrihydrite and no $\mathrm{NH}_{4}^{+}$, had a decreased diversity in their bacterial communities (Fig. 3, lanes 5-7). Samples supplied with both organic carbon $\left(1.00 \mathrm{mmol} \mathrm{L}^{-1}\right.$ sodium citrate $)$ and inorganic carbon $\left(1.20 \mathrm{mmol} \mathrm{L}^{-1} \mathrm{NaHCO}_{3}\right)$ had a higher bacterial diversity (DGGE Fig. 3, lane 8).

Changes in the microbial community after 180 days of incubation were also confirmed via 454 pyrosequencing, and the obvious growth of Actinobacteria, Acidobacteria and $\beta$ Proteobacteria groups (which bands A6, A8 and A9 belong to) was consistent with the DGGE results, where the Actinobacteria cell number increased the most (Fig. 4). The Planctomycetes phylum, with which anammox bacteria are affiliated, was detected in the first 90 days of incubation, but disappeared or was below detection on day 160. Actinobacteria were also the dominant species in the Feammox enrich-

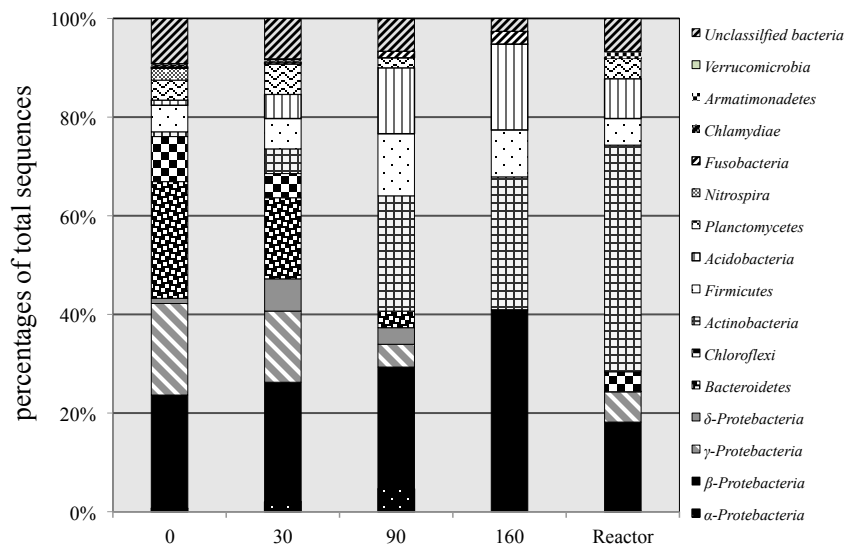

Figure 4. Relative abundance of bacterial phyla for each soil sample during anaerobic incubations (days $0,30,90,160$ ) and enrichment culture from the reactor.

ment reactor, based on the results of the 16S rDNA library obtained via pyrosequencing (Fig. 4).

The Acidimicrobiaceae bacterium, represented by band A6, which belongs to the Actinobacteria phylum, was the dominant species in the incubation experiments after 180 days of incubation (14.8\% of total $16 \mathrm{~S}$ rRNA gene sequences) as well as in the membrane reactor after 150 days of operation ( $40.2 \%$ of total 16S rRNA gene sequences). Its similarity to other Acidimicrobiaceae-related sequences is shown using a phylogenetic tree (Fig. 5). Unlike the bacteria represented by bands $\mathrm{A} 8$ and $\mathrm{A} 9$, which were also found in samples that did not show Feammox transformations, this Acidimicrobiaceae bacterium was only detected in incubations (or reactors) that were augmented simultaneously with ferrihydrite, $\mathrm{NH}_{4} \mathrm{Cl}$, and $\mathrm{NaHCO}_{3}$, and have shown Feammox activity (Fig. 3).

\subsection{Changes in bacterial abundance and activity during incubations and in the reactor}

The total bacterial abundance determined via the 16S rRNA gene copy number decreased during the 180-day incubation (Fig. 6). Both, 16S rRNA gene and rRNA fragment copies of Acidimicrobiaceae bacteria (DGGE band A6), increased during the incubation, particularly after 90 days. The rRNA numbers increased slowly during the first 3 months and doubled between day 130 and day 140 of the incubation period (Fig. 6). rRNA as a biomarker for changes in protein level, even though not as specific as mRNA, is a good indicator of bacterial activity (Poulsen et al., 1993; Park et al., 2010). The abundance of Acidobacteriaceae bacteria (DGGE band A8), and that of denitrifiers (represented by the number of copies of the nirS gene and the nirK gene), increased over the 180day incubation (Fig. S4a, b, c), although their growth over that period was less than that of the Acidimicrobiaceae bacteria (DGGE band A6). An increase in copies of the nirS and nirK genes showed similar trends, although the number 


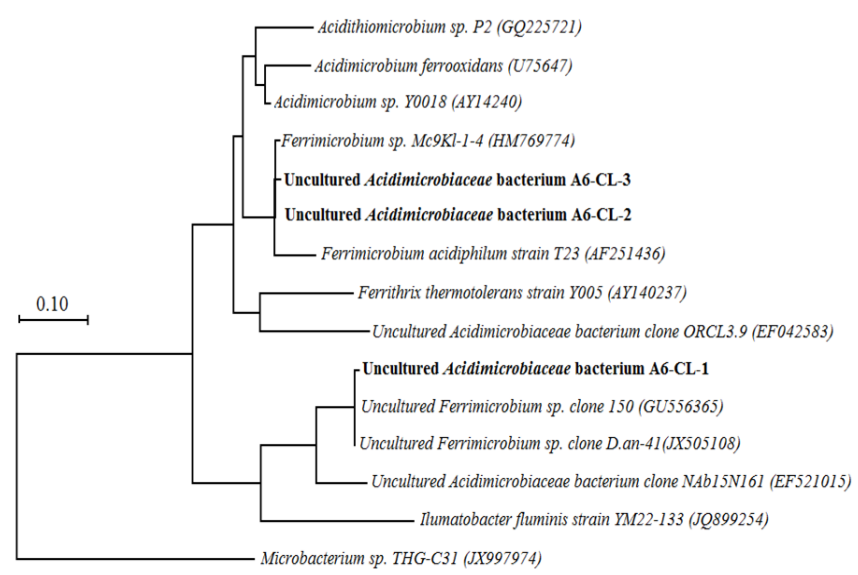

Figure 5. Phylogenetic tree of Acidimicrobiaceae-related sequences. The tree was constructed using the Bayesian inference (BI) method with 16S rRNA gene sequences from DGGE band A6 and bacteria from the Acidimicrobiaceae family from other studies. Sequences determined in this study are in bold. Bootstrap values were based on 1000 replicates each and are shown at the nodes with less than $50 \%$ bootstrap support. The scale bar represents $10 \%$ sequence divergence.

of nirK gene copies was 2 orders of magnitude lower than that of nirS (Fig. S4b, c). An increase in the denitrifier activity was most likely stimulated by the $\mathrm{NO}_{2}^{-}$generated via Feammox. The number of the amoA gene, representing the abundance of ammonia-oxidizing bacteria, decreased sharply with time, and was hardly detected after 90 days of incubation (Fig. S4e). Through quantification of thaumarchaeal amoA genes, none of the acidophilic ammonia oxidizers was detected in our system.

In the Feammox reactor, the copy numbers of Acidimicrobiaceae bacterium A6, Anammox bacteria and the nirS gene were $0.37 \times 10^{7}, 0.13 \times 10^{6}$, and $0.92 \times 10^{6}$ copies $\mathrm{g}^{-1} \mathrm{dw}$, respectively, while the amoA gene was not detected.

\subsection{Changes in bacterial abundance and activities with $\mathrm{NaHCO}_{3}$ amendment}

Abundance and activity of Acidimicrobiaceae bacteria, represented by band A6, were compared between samples incubated under the same conditions, except for the amounts of $\mathrm{NaHCO}_{3}$ added $\left(0.20 \mathrm{mmol} \mathrm{L}^{-1}\right.$ vs. $\left.1.20 \mathrm{mmol} \mathrm{L}^{-1}\right)$. From day 125 to day 180 of the incubation, both $16 \mathrm{~S}$ rRNA gene and rRNA fragment numbers of Acidimicrobiaceae bacteria were higher in the soils with the higher inorganic carbon content. The 16S rRNA gene copies of samples augmented with $1.20 \mathrm{mmol} \mathrm{L}^{-1} \mathrm{NaHCO}_{3}$ were four times higher than those in samples that had been augmented with only $0.20 \mathrm{mmol} \mathrm{L}^{-1} \mathrm{NaHCO}_{3}$ (Fig. 6). The rRNA copies of the Acidimicrobiaceae bacteria showed even larger differences in response to the amounts of $\mathrm{NaHCO}_{3}$ added. In the samples augmented with $1.20 \mathrm{mmol} \mathrm{L}^{-1} \mathrm{NaHCO}_{3}$,

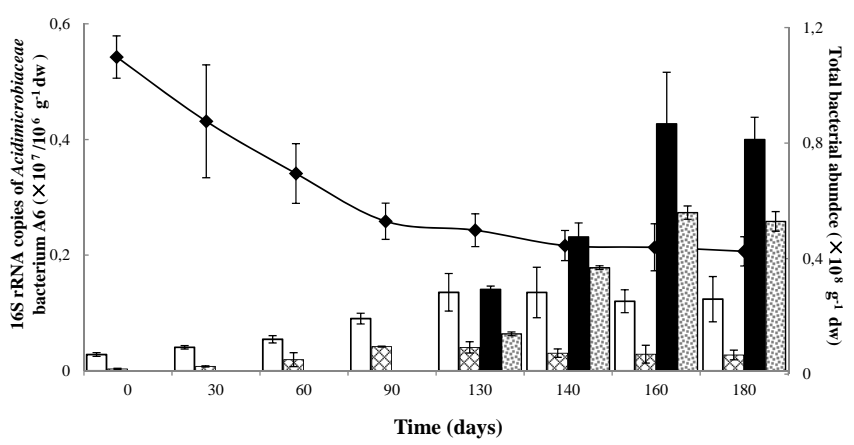

Figure 6. Abundance of total bacteria $(\$)$ during 180 days of anaerobic incubation. 16S rRNA gene ( $\square)$ and RNA (๑) copy numbers of Acidimicrobiaceae bacterium A6 in soil samples with $1.20 \mathrm{mmol} \mathrm{L}^{-1} \mathrm{NaHCO}_{3}$ addition. 16S rRNA gene ( $\square$ ) and RNA $(\otimes)$ copy numbers of bacterium A6 with $0.20 \mathrm{mmol} \mathrm{L}^{-1} \mathrm{NaHCO}_{3}$ addition.

the rRNA copy number increased from $0.04 \pm 0.06 \times 10^{6}$ to $0.19 \pm 0.09 \times 10^{6}$ copies $^{-1} \mathrm{dw}$ over 50 days of incubation (day 130 to day 180). However, in the samples to which only $0.2 \mathrm{mmol} \mathrm{L}^{-1} \mathrm{NaHCO}_{3}$ were added on day 125 , the rRNA number gradually deceased from $0.29 \pm 0.10 \times 10^{5}$ to $0.19 \pm 0.05 \times 10^{5}$ copies $\mathrm{g}^{-1} \mathrm{dw}$ during the same 50-day incubation (Fig. 6).

\subsection{Nitrogen species changes in samples incubated in the presence of $\mathrm{C}_{2} \mathrm{H}_{2}$}

$\mathrm{C}_{2} \mathrm{H}_{2}$ can inhibit the oxidation of $\mathrm{NH}_{4}^{+}$to $\mathrm{NO}_{2}^{-}$under aerobic conditions, and the reduction of $\mathrm{N}_{2} \mathrm{O}$ to $\mathrm{N}_{2}$ as well as the anammox pathway under anaerobic conditions (Yoshinari et al., 1977; Jensen et al., 2007; Kartal et al., 2011). To gain further insights into the nitrogen removal process observed, incubations with $\mathrm{C}_{2} \mathrm{H}_{2}$ were conducted. After 20 days of incubation, less $\mathrm{NH}_{4}^{+}$was oxidized in the samples amended with $\mathrm{C}_{2} \mathrm{H}_{2}$, compared to those incubated without $\mathrm{C}_{2} \mathrm{H}_{2}$ (Fig. S5a). $\mathrm{NO}_{2}^{-}$, which is postulated to be the direct product of the $\mathrm{NH}_{4}^{+}$oxidation, accumulated slowly in samples incubated with $\mathrm{C}_{2} \mathrm{H}_{2}$ (Fig. S5b). $\mathrm{NO}_{3}^{-}$reached a higher concentration in samples without $\mathrm{C}_{2} \mathrm{H}_{2}$ than in samples incubated with $\mathrm{C}_{2} \mathrm{H}_{2}$ (Fig. S5c). $\mathrm{N}_{2} \mathrm{O}$, a product of $\mathrm{NO}_{2}^{-}$reduction, accumulated in samples incubated with $\mathrm{C}_{2} \mathrm{H}_{2}$, which inhibits the reduction of $\mathrm{N}_{2} \mathrm{O}$ to $\mathrm{N}_{2}$ (Fig. S5d). $\mathrm{Fe}$ (II) production was not much affected by the presence of $\mathrm{C}_{2} \mathrm{H}_{2}$, and after 20 days incubation was $4.36 \pm 0.72$ and $5.71 \pm 0.67 \mathrm{mmol} \mathrm{L}^{-1}$ in sample incubated with and without $\mathrm{C}_{2} \mathrm{H}_{2}$, respectively.

In the ${ }^{15} \mathrm{~N}$ isotope tracer incubations, detectable ${ }^{15} \mathrm{~N}-\mathrm{N}_{2} \mathrm{O}$ was only found in samples amended with both, ${ }^{15} \mathrm{NH}_{4} \mathrm{Cl}$ and $\mathrm{Fe}(\mathrm{III})$, with ${ }^{15} \mathrm{~N}-\mathrm{N}_{2} \mathrm{O}$ production rates $2.14 \pm 0.059$ or $0.072 \pm 0.023 \mu \mathrm{g} \mathrm{g}^{-1} \mathrm{~d}^{-1}$ in samples incubated with or without $\mathrm{C}_{2} \mathrm{H}_{2}$ treatment (Table $\mathrm{S} 2$ ). 


\section{Discussion}

DGGE band A5 represents dissimilatory iron-reducing bacteria, which appeared for a short time at the beginning of the anaerobic incubation. For longer incubation times, these heterotrophic bacteria decreased rapidly (Fig. 3). Over a 25day incubation period, more than three times the mass of $\mathrm{Fe}$ (II) was produced in samples amended with ferrihydrite and $\mathrm{NH}_{4}^{+}$as compared to the samples amended only with ferrihydrite, indicating that most of the Fe(III) reduction came from the Feammox reaction, and not from dissimilatory Fe(III) reduction (Fig. 1a vs. Fig. S2a).

AOB represented by DGGE band A7 (Fig. 3), as well as the amoA gene, decreased after 30 days of incubation (Fig. S4e). Also, no AOA or acidophilic ammonia oxidizers were detected, although the $\mathrm{pH}$ condition seems suitable for them in these incubations. Oxygen deficiency was the most likely reason for the decline in AOB in this system over time (Laanbroek et al., 1994). Even though a small amount of AOB would be enough for $\mathrm{NH}_{4}^{+}$oxidation, in our control samples to which no $\mathrm{Fe}(\mathrm{III})$ was added, which AOB do not require, no $\mathrm{NH}_{4}^{+}$consumption was detected (Fig. S2). Moreover, the decrease in the amoA gene at a time of increasing $\mathrm{NH}_{4}^{+}$oxidation also indicates that neither $\mathrm{AOB}$ nor acidophilic ammonia oxidizers were the drivers of the $\mathrm{NH}_{4}^{+}$ oxidation in the later incubation times.

An uncultured Acidimicrobiaceae bacterium became the dominant species during the 180-day anaerobic incubation period, increasing from $0.92 \%$ on day 0 in terms of cell numbers to $14.8 \%$ on day 160 . In the incubation experiments conducted (which included controls with only $\mathrm{NH}_{4}^{+}$, only iron, autoclaved, and various Fe(III) sources), this Acidimicrobiaceae bacterium was only detected and growing in samples to which $\mathrm{NH}_{4}^{+}$was supplied as an electron donor, ferrihydrite was supplied as electron acceptor, and $\mathrm{NaHCO}_{3}$ was supplied as a carbon source (Figs. 1, 3, S1, S2). The abundance and activity of this Acidimicrobiaceae bacterium increased along with the Feammox activity during the incubations. During the incubation period its rRNA changed from $(0.22 \pm 0.01) \times 10^{5}$ copies $\mathrm{g}^{-1} \mathrm{dw}$ to $(0.28 \pm 0.07) \times 10^{6}$ copies $\mathrm{g}^{-1} \mathrm{dw}$, indicating a substantial increase in its activity (Fig. 6). In the continuous flow membrane reactor, which had a high $\mathrm{NH}_{4}^{+}$removal and $\mathrm{Fe}(\mathrm{III})$ reduction rate, this Acidimicrobiaceae bacterium was enriched from an initial 14.8 to $40.2 \%$ after 150 days operation, and no other known $\mathrm{NH}_{4}^{+}$oxidizers (AOB or anammox) were detected (Fig. 4). These results indicated that this Acidimicrobiaceae bacterium might play an important role in the Feammox reactions described in this study. According to a phylogenetic analysis, this bacterium has a $92 \%$ identity with Ferrimicrobium acidiphilum sp. (Table 1). F. acidiphilum, which belongs to the Acidimicrobiaceae family, was first isolated from mine environments (Johnson et al., 2009), and $F$. acidiphilum strain T23 is the only pure strain with a comprehensive characterization. Uncultured Ferrimicrobium sp. has been detected in mine water, but so far not in wetland soils (Gonzalez-Toril et al., 2003; Johnson et al., 2009; Bruneel et al., 2011). Ferrimicrobium sp. is an acidophilic heterotrophic ferrous iron oxidizing bacterium, which can also reduce $\mathrm{Fe}$ (III) under anoxic conditions (Johnson et al., 2009). The uncultured Acidimicrobiaceae bacterium, also has a $90 \%$ identity with Acidimicrobium ferrooxidans (Table 1), a facultative autotroph in the same family, which can reduce $\mathrm{Fe}(\mathrm{III})$ in anaerobic environments while oxidizing sulfide to sulfur, and exists widely in soil environments (Clark and Norris, 1996; Bond et al., 2000; Hartmann et al., 2009).

According to a phylogenetic comparison with similar clones from studies reported in the GenBank (Fig. 5), and taking into account its special growth characteristics (stimulated by inorganic carbon, oxidizing $\mathrm{NH}_{4}^{+}$coupled to $\mathrm{Fe}(\mathrm{III})$ reduction), also its gradual activity increase with increased Feammox activity, as well as a strong link with a Feammox enrichment reactor, this uncultured Acidimicrobiaceae bacterium A6 is probably a previously unreported species in the Acidimicrobiaceae family that might be either responsible or play a key role in the Feammox process described here. Acidimicrobiaceae bacterium A6 was more active and the Feammox pathway was faster in samples with higher $\mathrm{NaHCO}_{3}$ amendments (Figs. 2 and 6), which, in addition to the fact that $\Delta G$ in Eq. (1) is negative, indicates that if this Acidimicrobiaceae bacterium is actually responsible for conducting the Feammox reaction as depicted in Eq. (1), it may be an autotroph. Growth of the nirS gene suggested that denitrification pathways were also active in the incubations described here. $\mathrm{NO}_{2}^{-}$that was being produced during the anaerobic $\mathrm{NH}_{4}^{+}$oxidation was reduced to $\mathrm{N}_{2}$ by denitrifiers, and $\mathrm{NO}_{2}^{-}$did not accumulate in the system.

The Feammox reaction studied here proceeded only when iron oxides (ferrihydrite or goethite) were supplied as electron acceptor, whereas samples incubated with ferric chloride or ferric citrate as the $\mathrm{Fe}(\mathrm{III})$ source showed no measurable $\mathrm{NH}_{4}^{+}$oxidation (Figs. 1 and $\mathrm{S} 1$ ). In the incubations to which ferric citrate was added as the Fe(III) source, Fe(III) was reduced rapidly by dissimilatory iron reducers, using organic carbon as electron donor. The DGGE results for incubations with ferric citrate (Fig. 3, lane 7) show that the most dominant species was an Actinobacterium (Table S1), known to reduce iron under anaerobic conditions (Lin et al., 2007; Lentini et al., 2012). Acidimicrobiaceae bacterium A6 was not detected in these incubations. Since acidic conditions as well as minimal dissolved $\mathrm{Fe}(\mathrm{II})$ and $\mathrm{NO}_{2}^{-}$concentrations are required to make the Feammox reaction energetically favorable as shown in Eq. (1), the presence of iron oxides as the main $\mathrm{Fe}$ (III) source may have helped to maintain the concentrations of $\mathrm{Fe}$ (II) in solution below the detection limit through the incubation since iron oxides can sorb Fe(II) and/or incorporate it into their structure.

Various $\mathrm{NH}_{4}^{+}$oxidation products, i.e., $\mathrm{NO}_{3}^{-}, \mathrm{NO}_{2}^{-}$ and $\mathrm{N}_{2}$, generated through the Feammox process, are 
thermodynamically feasible, and were reported in different Feammox studies (Sawayama, 2006; Shrestha et al., 2009; Yang et al., 2012). Because there was no initial nitrate or nitrite in the system, because all experiments were conducted under strict oxygen-free conditions, and because of the rapid decrease in amoA genes, neither $\mathrm{NO}_{3}^{-}$reduction nor aerobic $\mathrm{NH}_{4}^{+}$oxidation could be the reason for the formation of $\mathrm{NO}_{2}^{-}$during the incubations. In all incubations where $\mathrm{NH}_{4}^{+}$ was removed, the production of $\mathrm{NO}_{2}^{-}$was observed, although $\mathrm{NO}_{2}^{-}$did not accumulate. Most of the $\mathrm{NO}_{2}^{-}$produced from the $\mathrm{NH}_{4}^{+}$oxidation was reduced rapidly by denitrifiers, which were present in the incubations.

When $\mathrm{C}_{2} \mathrm{H}_{2}$ was used to stop the reduction of $\mathrm{N}_{2} \mathrm{O}$ to $\mathrm{N}_{2}$, the total $\mathrm{N}_{2} \mathrm{O}\left(0.72 \pm 0.23 \mathrm{mmol} \mathrm{L}^{-1}\right)$ plus $\mathrm{NO}_{2}^{-}$produced $\left(0.13 \pm 0.07 \mathrm{mmol} \mathrm{L}^{-1}\right)$ was equal to the $\mathrm{NH}_{4}^{+}$consumed, showing that $\mathrm{NH}_{4}^{+}$was not oxidized directly to $\mathrm{N}_{2}$ in our samples. ${ }^{15} \mathrm{~N}-\mathrm{NH}_{4}^{+}$incubations, as an extension of $\mathrm{C}_{2} \mathrm{H}_{2}$ treatment, showed that ${ }^{15} \mathrm{~N}-\mathrm{N}_{2} \mathrm{O}$ built up when ${ }^{15} \mathrm{NH}_{4} \mathrm{Cl}$ was added as the $\mathrm{NH}_{4}^{+}$source (Table S2), demonstrating that $\mathrm{NH}_{4}^{+}$was oxidized during the Feammox process rather than adsorbed or taken up by microorganisms in the system.

Although nitrification might happen in suboxic environments (oxygen $<5 \mu \mathrm{M}$, Lam et al., 2007), $\mathrm{NH}_{4}^{+}$oxidation in the presence of $\mathrm{C}_{2} \mathrm{H}_{2}$ has never been reported. $\mathrm{C}_{2} \mathrm{H}_{2}$ is an inhibitor of ammonia monooxygenase (AMO), and can restrain aerobic $\mathrm{NH}_{4}^{+}$oxidizers from using oxygen by binding covalently to AMO (Hynes and Knowles, 1982; Hyman and Wood, 1985; Gilch et al., 2009). $\mathrm{C}_{2} \mathrm{H}_{2}$ can also inhibit the $\mathrm{NH}_{4}^{+}$-activation step of anammox cells, which use $\mathrm{NO}_{2}^{-}$as the oxidant (Kartal et al., 2011). Therefore, these Feammox bacteria might differ from common $\mathrm{NH}_{4}^{+}$oxidizers, by using an alternative $\mathrm{NH}_{4}^{+}$oxidation pathway that is not inhibited by $\mathrm{C}_{2} \mathrm{H}_{2}$, and AMO might not play a role in Feammox. The fact that $\mathrm{NH}_{4}^{+}$oxidation was not affected by the presence of acetylene is a further indication that $\mathrm{AOB}$ are not responsible for this process since they would be affected by acetylene. Furthermore, in the isotope tracer incubations, ${ }^{15} \mathrm{~N}-\mathrm{N}_{2} \mathrm{O}$ was below the detection limit in samples to which Fe(III) was not supplied, showing again that $\mathrm{NH}_{4}^{+}$oxidation proceeded only when iron was being reduced.

The role of anammox during the incubations was also evaluated. During the incubations the ratio of $\mathrm{NH}_{4}^{+}$oxidized to $\mathrm{Fe}(\mathrm{III})$ reduced increased gradually from $1: 1.9$ to $1: 5.3$ (Fig. S6), which is close to the stoichiometry of $1: 6$, shown in Eq. (1). Although the discrepancies in the Feammox stoichiometry between iron and $\mathrm{NH}_{4}^{+}$are attributed in part to incompletely $\mathrm{Fe}$ (II) extraction, the influence of anammox activity in the earlier incubations would have contributed to a lower $\mathrm{Fe}(\mathrm{II})$ produced to $\mathrm{NH}_{4}^{+}$removed ratio than the theoretical value of $1: 6$.

The Feammox reaction became more dominant in terms of $\mathrm{NH}_{4}^{+}$oxidation after 125 days of incubation due to a relative increase in the activity of the Feammox bacteria. A parallel pathway to Feammox, such as anammox, could, as mentioned above, explain the lower stoichiometric ratio, especially at earlier incubation times. In the samples

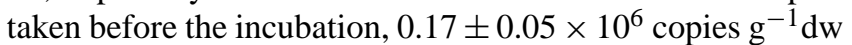
of the anammox rRNA gene were found, which decreased to $0.09 \pm 0.06 \times 10^{5}$ on day 130 (Fig. S4d). We postulate that anammox was responsible for some initial $\mathrm{NH}_{4}^{+}$and $\mathrm{NO}_{2}^{-}$removal, and denitrification became more dominant for $\mathrm{NO}_{2}^{-}$removal later during the incubation period (Fig. 5 and Fig. $\mathrm{S} 4 \mathrm{~b}, \mathrm{~d}) . \mathrm{NH}_{4}^{+}$removal via anammox in the early incubations may also explain why the observed $\mathrm{NH}_{4}^{+}$oxidation rates and the abundance of Acidimicrobiaceae A6 did not change proportionally over the full incubation period.

The results and analyses described here have shown that a Feammox enrichment reactor has the capacity to oxidize $\mathrm{NH}_{4}^{+}$coupled to iron reduction under anaerobic conditions, and that an uncultured Acidimicrobiaceae bacterium A6, which became the dominant species over time, might be responsible for this Feammox reaction. Without access to samples from other reported biological $\mathrm{NH}_{4}^{+}$oxidation by $\mathrm{Fe}(\mathrm{III})$ reducers (Sawayama, 2006; Yang et al., 2012), it is not possible to know if the organisms for the processes reported by these investigators are the same as those identified here. Conclusive linkage between Acidimicrobiaceae A6 and the Feammox process requires the isolation of the strain and then the conducting of incubations with the pure strain. At this point, the observations (i) that $\mathrm{NH}_{4}^{+}$removal only occurred in samples when the presence of Acidimicrobiaceae bacterium A6 was detected and when iron was being reduced, (ii) that Acidimicrobiaceae A6 numbers increased gradually after sequential $\mathrm{NH}_{4}^{+}$and $\mathrm{Fe}(\mathrm{III})$ additions, and (iii) the results from the enrichment culture that was operated for an extended time period while only adding $\mathrm{NH}_{4}^{+}$and iron oxide sources and during which Acidimicrobiaceae A6 became the dominant bacterial species, while no other known $\mathrm{NH}_{4}^{+}$oxidizer $(\mathrm{AOB}$ or anammox) was detected after 150 days of operation, indicate that Acidimicrobiaceae A6 is likely to play an important role in the oxidation of $\mathrm{NH}_{4}^{+}$under iron reduction conditions.

\section{The Supplement related to this article is available online at doi:10.5194/bg-12-769-2015-supplement.}

Acknowledgements. This research was supported by Project $\mathrm{X}$ from Princeton University. We thank L. Young, J. Stock, A. Mumford and S. Zhang for technical assistance.

Edited by: J. Middelburg

\section{References}

Abbassi, R., Yadav, A. K., Huang, S., and Jaffé, P. R.: Laboratory Study of Nitrification, Denitrification and Anammox Processes 
in Membrane Bioreactors Considering Periodic Aeration, J. Environ. Manage., 142, 53-59, 2014.

Bond, P. L., Druschel, G. K., and Banfield, J. F.: Comparison of Acid Mine Drainage Microbial Communities in Physically and Geochemically Distinct Ecosystems, Appl. Environ. Microbiol., 66, 4962-4971, 2000.

Braker, G., Fesefeldt, A., and Witzel, K. P.: Development of PCR primer systems for amplification of nitrite reductase genes (nirK and nirS) to detect denitrifying bacteria in environmental samples, Appl. Environ. Microbiol., 64, 3769-3775, 1998.

Bruneel, O., Volant, A., Gallien, S., Chaumande, B., Casiot, C., Carapito, C., Bardil, A., Morin, G., Brown, G. E. Jr., Personné, C. J., Le Paslier, D., Schaeffer, C., Van Dorsselaer, A., Bertin, P. N., Elbaz-Poulichet, F., and Arsène-Ploetze, F.: Characterization of the active bacterial community involved in natural attenuation processes in arsenic-rich creek sediments, Microb. Ecol., 61, 793-810, 2011.

Canfield, D. E., Glazer, A. N., and Falkowski, P. G.: The evolution and future of earth's nitrogen cycle, Science, 330, 192-196, 2010.

Clark, D. A. and Norris, P. R.: Acidimicrobium ferrooxidans gen. nov., sp. nov.: mixed-culture ferrous iron oxidation with Sulfobacillus species, Microbiology, 142, 785-790, 1996.

Clement, J. C., Shrestha, J., Ehrenfeld, J. G., and Jaffé, P. R.: Ammonium oxidation coupled to dissimilatory reduction of iron under anaerobic conditions in wetland soils, Soil Biol. Biochem., 37, 2323-2328, 2005.

Cornell, R. M. and Schwertmann, U.: The Iron Oxides: Structure, Properties, Reactions, Occurrences, and Uses, John Wiley and Sons Ltd., 2003.

Coupland, K. and Johnson, D. B.: Evidence that the potential for dissimilatory ferric iron reduction is widespread among acidophilic heterotrophic bacteria, FEMS Microbiol. Lett., 279, 3035, 2008.

Francis, C. A., Roberts, K. J., Beman, J. M., Santoro, A. E., and Oakley, B. B.: Ubiquity and diversity of ammonia-oxidizing archaea in water columns and sediments of the ocean, Proc. Natl. Acad. Sci., 102, 14683-14688, 2005.

Gilch, S., Meyer, O., and Schmidt, I.: A soluble form of ammonia monooxygenase from Nitrosomonas europaea, Biol. Chem., 390, 863-873, 2009.

Gonzalez-Toril, E., Llobet-Brossa, E. O., Casamayor, R., Amann, R., and AmilsMicrobial, R.: Microbial ecology of an extreme acidic environment, the Tinto River, Appl. Environ. Microbiol., 69, 4853-4865, 2003.

Harms, G., Layton, A. C., Dionisi, H. M., Gregory, I. R., Garrett, V. M., Hawkins, S. A., Robinson, K. G., and Sayler, G. S.: Realtime PCR quantification of nitrifying bacteria in a municipal wastewater treatment plant, Environ. Sci. Technol., 37, 343-351, 2003.

Hartmann, M., Lee, S., Hallamand, S. J., and Mohn, W. W.: Bacterial, archaeal and eukaryal community structures throughout soil horizons of harvested and naturally disturbed forest stands, Environ. Microbiol., 11, 3045-3062, 2009.

Huang, S., Chen, C., Yang, X., Wu, Q., and Zhang, R.: Distribution of typical denitrifying functional genes and diversity of the nirSencoding bacterial community related to environmental characteristics of river sediments, Biogeosciences, 8, 5251-5280, 2011, http://www.biogeosciences.net/8/5251/2011/.
Huelsenbeck, J. P., Ronquist, F. R., Nielsen, R., and Bollback, J. P.: Bayesian inference of phylogeny and its impact on evolutionary biology, Science, 294, 2310-2314, 2001.

Hyman, M. R. and Wood, P. M.: Suicidal inactivation and labeling of ammonia monooxygenase by acetylene, Biochem. J., 227, 719-725, 1985.

Hynes, R. K. and Knowles, R.: Effect of acetylene on autotrophic and heterotrophic nitrification, Can. J. Microbiol., 28, 334-340, 1982.

Jensen, M. M., Thamdrup, B., and Dalsgaard, T.: Effect of specific inhibition on anammox and denitrification in marine sediments, Appl. Environ. Microbiol., 73, 3151-3158, 2007.

Jensen, S., Øvreås, L., Daae, F. L., and Torsvik, V.: Diversity in methane enrichments from agricultural soil revealed by DGGE separation of PCR amplified 16 s rDNA fragments, FEMS Microbiol. Ecol., 26, 17-26, 1998.

Johnson, D. B., Bacelar-Nicolau, P., Okibe, N., Thomas, A., and Hallberg, K. B.: Characteristics of Ferrimicrobium acidiphilum gen. nov., sp. nov., and Ferrithrix thermotolerans gen. nov., sp. nov.: heterotrophic iron-oxidizing, extremely acidophilic actinobacteria, Int. J. Syst. Evol. Microbiol., 59, 1082-1089, 2009.

Kartal, B., Maalcke, W. J., de Almeida, N. M., Cirpus, I., Gloerich, J., Geerts, W., Op den Camp, H. J. M., Harhangi, H. R., JanssenMegens, E. M., Francoijs, K., Stunnenberg, H. G., Keltjens, J. T., Jetten, M. S. M., and Strous, M.: Molecular mechanism of anaerobic ammonium oxidation, Nature, 479, 127-130, 2011.

Kishimoto, N., Kosako, Y., and Tano, T.: Acidobacterium capsulatum gen. nov., sp. nov.: an acidophilic chemoorganotrophic bacterium containing menaquinone from acidic mineral environment, Curr. Microbiol., 22, 1-7, 1991.

Komlos, J., Kukkadapu, R. K., Zachara, J. M., and Jaffé, P. R.: Biostimulation of Iron Reduction and Subsequent Oxidation of Sediment Containing Fe-silicates and Fe-oxides: Effect of Redox Cycling on Fe(III) Bioreduction, Water Res., 41, 2996-3004, 2007.

Laanbroek, H. J., Bodelier, P. L. E., and Gerards, S.: Oxygen consumption kinetics of Nitrosomonas europaea and Nitrobacter hamburgenis grown in mixed continuous cultures at different oxygen concentrations, Arch. Microbiol., 161, 156-162, 1994.

Lam, P., Jensen, M. M., Lavik, G., McGinnis, D. F., Müller, B., Schubert, C. J., Amann, R., Thamdrup, B., and Kuypers, M. M. M.: Linking crenarchaeal and bacterial nitrification to anammox in the Black Sea, Proc. Natl. Acad. Sci. USA, 104, 7104-7109, 2007.

Park, H., Rosenthal, A., Ramalingam, K., Fillos, J., and Chandran, K.: Linking community profiles, gene expression and N-removal in anammox bioreactors treating municipal anaerobic digestion reject water, Environ. Sci. Technol., 44, 6110-6116, 2010.

Pinto, A. J. and Raskin, L.: PCR biases distort bacterial and archaeal community structure in pyrosequencing datasets, PLoS One, 7, 43093, doi:10.1371/journal.pone.0043093, 2012.

Poulsen, L. K., Ballard, G., and Stahl, D. A.: Use of rRNA fluorescence in situ hybridization for measuring the activity of single cells in young and established biofilms, Appl. Environ. Microbiol., 59, 1354-1360, 1993.

Rosenzweig, B. R., Smith, J. A., Baeck, M. L., and Jaffé, P. R.: Monitoring Nitrogen Loading and Retention in an Urban Stormwater Detention Pond, J. Environ. Qual., 40, 598-609, 2011. 
Rotthauwe, J. H., Witzel, K. P., and Liesack, W.: The ammonia monooxygenase structural gene amoA as a functional marker: molecular fine-scale analysis of natural ammonia-oxidizing populations, Appl. Environ. Microbiol., 63, 4704-4712, 1997.

Rowe, O. F., Sánchez-España, J., Hallberg, K. B., and Johnson, D. B.: Microbial communities and geochemical dynamics in an extremely acidic, metal-rich stream at an abandoned massive sulfide mine (Huelva, Spain) underpinned by two primary production systems, Environ. Microbiol., 9, 1761-1771, 2007.

Sawayama, S.: Possibility of anoxic ferric ammonium oxidation, J. Biosci. Bioeng, 101, 70-72, 2006.

Schmid, M., Twachtmann, U., Klein, M., Strous, M., Juretschko, S., Jetten, M., Metzger, J. W., Schleifer, K., and Wagner, M.: Molecular evidence for genus level diversity of bacteria capable of catalyzing anaerobic ammonium oxidation, Syst. Appl. Microbiol., 23, 93-106, 2000.

Schmid, M., Walsh, K., Webb, R., Rijpstra, W. I., van de PasSchoonen, K., Verbruggen, M. J., Hill, T., Moffett, B., Fuerst, J., Schouten, S., Damsté, J. S., Harris, J., Shaw, P., Jetten, M., and Strous, M.: Candidatus "Scalindua brodae," sp. nov., Candidatus "Scalindua wagneri", sp. nov., two new species of anaerobic ammonium oxidizing bacteria, Syst. Appl. Microbiol., 26, 529-538, 2003.

Shrestha, J., Rich, J., Ehrenfeld, J., and Jaffé, P. R.: Oxidation of ammonium to nitrite under iron-reducing conditions in wetland soils: Laboratory, field demonstrations, and push-pull rate determination, Soil Sci., 174, 156-164, 2009.
Smith, R. L., Buckwalter, S. P., Repert, D. A., and Miller, D. N.: Small-scale, hydrogen-oxidizing-denitrifying bioreactor for treatment of nitrate-contaminated drinking water, Water Res., 39, 2014-2023, 2005.

Stookey, L. L.: Ferrozine-a new spectrophotometric reagent for iron, Anal. Chem., 42, 779-781, 1970.

Tourna, M., Freitag, T. E., Nicol, G. W., and Prosser, J. I.: Growth, activity and temperature responses of ammonia oxidising archaea and bacteria in soil microcosms, Environ. Microbiol., 10, $1357-$ 1364, 2008.

Van de Graaf, A. A., de Bruijn, P., Robertson, L. A., Jetten, M. S. M., and Kuenen, J. G.: Autotrophic growth of anaerobic ammonium-oxidizing micro-organisms in a fluidized bed reactor, J. Microbiol., 142, 2187-2196, 1996.

Yang, W. H., Weber, K. A., and Silver, W. L.: Nitrogen loss from soil through anaerobic ammonium oxidation coupled to iron reduction, Nat. Geosc., 5, 538-541, 2012.

Yoshinari, T., Hynes, R., and Knowles, R.: Acetylene inhibition of nitrous oxide reduction and measurement of denitrification and nitrogen fixation in soil, Soil Biol. Biochem., 9, 177-183, 1977. 